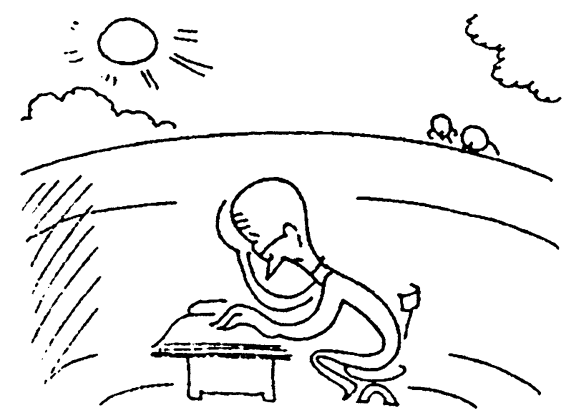

\title{
WHO IS LEARNED?
}

\author{
A definition
}

One who, consuming midnight oil in studies diligent and slow, teaches himself, with painful toil, that things that other people know.

\section{Piet Hein}

Copyright (C) Piet Hein Illustration \& Grook

Reprinted with kind permission from Piet Hein a/s, Middelfart, Denmark 